\title{
Model Pendidikan Keibubapaan Abdullah Nasih Ulwan (MPIU) dalam Menangani Isu Remaja Lari dari Rumah ${ }^{1}$
}

\author{
Che Zarrina $\mathrm{Sa}^{\text {‘ }}$ ari \\ Universiti Malaya, zarrina@um.edu.my \\ Sharifah Basirah Syed Muhsin \\ Universiti Malaya, basirah@um.edu.my \\ Siti Sarah Ahmad \\ Universiti Malaya, sarahahmad287@gmail.com \\ Faizuri Abd Latif \\ Universiti Malaya,fa72@um.edu.my \\ DOI: https://doi.org/10.22452/usuluddin.sp2019no1.4
}

\begin{abstract}
Abstrak
Isu pendidikan ibu bapa tidak pernah leka diperkatakan dalam masyarakat, apatah lagi dengan gaya hidup moden masyarakat dan keluarga masa kini. Isu ini sering kali dikaitkan dengan peningkatan masalah sosial melibatkan para remaja di Malaysia saban tahun. Pelbagai kajian dilakukan untuk cuba menangani ataupun mengurangi masalah yang berlaku dan antara lainnya ialah menilai semula peranan ibu bapa dan guru terhadap golongan ini. Salah satu isu dikaitkan dengan golongan remaja ialah masalah lari dari rumah. Menurut statistik 2010 yang dikeluarkan oleh Polis Diraja Malaysia (PDRM) menunjukkan kes remaja lari dari rumah meningkat dengan angka mencatatkan sebanyak 4,097 remaja membabitkan seawal usia 13 hingga 17 tahun. Hal ini berpunca daripada pelbagai faktor pendorong kepada peningkatan isu ini, namun terdapat kajian menunjukkan antara faktor pendorong utama berlakunya gejala ini berpunca dari corak dan bentuk didikan institusi keluarga itu sendiri khususnya didikan ibu bapa. Ini kerana peranan yang dimainkan oleh ibu bapa dalam mendidik anak-anak mereka amat penting bagi membentuk spiritual dan perilaku remaja sama ada menjurus kepada pembentukan jati diri positif ataupun negatif. Memandangkan perkara ini adalah sesuatu yang amat penting, maka pendekatan para ilmuwan yang membincangkan kaedah pendidikan anak-anak boleh dikaji dan diteliti serta dibangunkan satu model pendidikan keibubapaan yang bersesuaian dalam menangani isu remaja khususnya lari dari rumah. Oleh itu, kajian ini cuba mengambil iktibar dari pemikiran tokoh terkenal pendidikan anak-anak, Abdullah Nasih Ulwan untuk membentuk sebuah "Model Pendidikan Keibubapaan Ulwan (MPIU)" dengan menjurusi perbincangan yang dibuat dalam kitab
\end{abstract}

1 Sebahagian laporan penyelidikan UMRG RG310-11HNE. 
Tarbiyah al-Awlad kerana ia dilihat mempunyai elemen serta metode pendidikan melibatkan psikologi dan sosiologi yang lengkap bagi membantu membangunkan jiwa remaja ke arah yang lebih baik.

Kata kunci: pendidikan keibubapaan, Abdullah Nasih Ulwan, remaja lari dari rumah

\title{
'Abdullah Nasih 'Ulwan Parenting Model (MPIU) in Dealing with Adolescents Running Away from Home
}

\begin{abstract}
The issue of parental education has never been addressed in the society, let alone in modern society and family life today. This issue is often associated with increasing social problems involving teenagers in Malaysia every year. Various studies have been conducted to try to address or minimize the problems that occur, among others, to reevaluate the role of parents and teachers in this group. One of the issues associated with teenagers is the problem of running away from home. According to 2010 statistics released by the Royal Malaysian Police (PDRM), the number of teenagers running away from home increased with a 4,097 teenagers ranging from ages 13 to 17. This is due to various factors contributing to the rise of the issue, but there are studies showing that the main driving force behind the symptom is due to the nature and form of education of the family institution itself, especially the parents' education. This is because the role that parents play in educating their children is crucial for the spiritual and behavioral development of adolescents whether it leads to positive or negative selfesteem since this is a very important issue, who approach and methods to educate children is significant to be studied. Therefore, this study seeks to extract some lessons on the thinking of the well-known child education leader Abdullah Nasih Ulwan to form a "Model of Ulwan Parenting Education (MPIU)" through the discussion made in his book entitled Tarbiyah al-Awlad as it is seen to have elements as well as educational methods that involve the comprehensive aspects of psychology and sociology to help develop adolescents' lives in a better way.
\end{abstract}

Keywords: parenting education, Abdullah Nasih Ulwan, teenagers running away from home

\section{Pendahuluan}

Perbincangan dan perbahasan mengenai "zaman remaja (adolescent) yang penuh dengan ketegangan dan badai" telah bermula seawal zaman Greek oleh Plato dan Aristotle lagi. Plato (1953) mendeskripsikan remaja lelaki sebagai “constantly arguing 
and very easily excited". ${ }^{2}$ Aristotle pula menghuraikan mereka sebagai "lacking in sexual self-restraint, fickle in their desires, passionate and impulsive". ${ }^{3}$ Kemudiannya, ketika zaman pertengahan, zaman remaja (adolescent) ini tidak lagi dikategorikan sebagai salah satu period kehidupan, malah mereka hanya dikenali sebagai orang dewasa kecil (small adults). Namun, Rousseau telah dikatakan sebagai orang pertama yang menentukan perbezaan antara dua zaman tersebut. Beliau telah menerangkan maksud adolescence sebagai " $a$ change in humour, frequent anger, a mind in constant agitation, makes the child almost unmanageable. His feverishness turns him into a lion. He disregards his guide; he no longer wishes to be governed" (Rousseau, 1911: 211). ${ }^{4}$

Selepas itu, istilah remaja (adolescent) terus digunakan dan zaman mereka dinamakan sebagai "The Age of Adolescence". Justeru, adolscere telah diberi makna sebagai membesar atau membesar menjadi matang. Terma remaja sebagaimana yang diutarakan oleh Santrock berdasarkan perspektif perkembangan hayat (life-span development). Tempoh masa berlakunya perkembangan peralihan dari zaman kanak-kanak ke alam awal dewasa yang biasanya bermula dalam lingkungan 10-12 tahun dan berakhir pada 18-22 tahun. Waktu remaja dimulai dengan perubahan fizikal yang pesat membabitkan perkembangan secara kuantitatif seperti ketinggian dan berat, perubahan bentuk badan serta ciri-ciri seksual dan sebagainya. Remaja juga akan mengalami perubahan drastik secara kualitatif yang melibatkan perkembangan mental dan spiritual dan psikomotor ${ }^{5}$.

Selain itu juga, alam baligh sering dikaitkan dengan permulaan remaja yang dilihat agak berbeza menurut individu dan gender. Anak-anak perempuan pada kebiasaannya mengalami baligh lebih awal berbanding kanak-kanak lelaki dengan kedatangan haid pertama. Dalam Islam, tahap baligh dikira

2 "Theories of Adolescence", laman sesawang UK Essays, dicapai pada, 4 Jan 2013, http://www.ukessays.com/essays/psychology/theories-ofadolescence.php.

3 Aristotle, Ethica Nichomachea (New York: Random House, 1941), 84.

4 Jean Jacques Rousseau, Emile or on Education (USA: Basic Books, 1979), 211.

5 John W Santrock, Life Span Development (United Kingdom: McGraw-Hill, 2009), 354-365. 
sebagai tahap permulaan segala amal perbuatan mula diperhitungkan dan mereka dikenakan hukuman dosa dan pahala. Justeru, mereka yang telah memasuki alam baligh ini mempunyai tanggungjawab yang lebih besar berbanding dengan zaman kanakkanak $^{6}$.

Merujuk kepada umur remaja, kajian psikologi perkembangan di Malaysia pada kebiasaan mengambil kira umur remaja dari 13-20 tahun iaitu bermula dengan permulaan mereka menduduki sekolah menengah dan berakhir apabila mereka melangkah kaki ke universiti. Oleh yang demikian, kajian ini akan menggunakan definisi yang dipakai dalam bidang psikologi perkembangan bahawa individu yang berusia 13-20 tahun dianggap sebagai remaja. Namun demikian, sekiranya diambil kira dari sudut undang-undang negara, individu yang berusia 18 tahun dan ke bawah masih diistilahkan sebagai kanak-kanak.

Dalam mengkategorikan remaja, terdapat ahli Psikologi Islam membahagikan peringkat remaja kepada empat peringkat. Pertama peringkat remaja yang disebut al-murāhaqah iaitu lingkungan umur 12- 15 tahun. Pada peringkat ini berlaku proses pertumbuhan dan perkembangan yang cepat dari sudut kuantitatif dan juga kualitatif. Kemudian peringkat kedua ialah disebut sebagai yaqu iaitu mulai 15-18 tahun. Pada peringkat ini pertumbuhan tubuh badan tetap berterusan akan tetapi kadar prosesnya agak kurang jika dibandingkan pada peringkat pertama. Pada peringkat ketiga pula, remaja dikenali sebagai al-shabāb al-mubaqir yang berumur dari 18 -21 tahun. Manakala pada peringkat ke-empat pula iaitu peringkat pemuda yang telah sampai baligh atau disebut sebagai al-shabāb al-bāligh iaitu dalam lingkungan 21-25 tahun ${ }^{7}$.

Oleh yang demikian, dapat difahami bahawa remaja adalah suatu proses dan bukannya suatu jangka masa. Proses ini pula boleh dimaknakan sebagai proses mencapai sesuatu atau memperolehi sikap dan kepercayaan yang diperlukan demi

6 Wahbah Al-Zuhayli, Ușūl al-Fiqh al-Islāmī (Damsyik: Dār al-Fikr, 1986), 158-159; Zinudin, Seluk Beluk Pendidikan Menurut al-Ghazali (Jakarta: Bumi Aksara, 1991), 69.

7 'Umar Muhammad al-Tūmī al-Shaban̄̄, Al-Usus al-Nafsiyyah wa alTarbawiyyah li Ria'yatī al-Syabāb (Beirut: Dār al-'Arabiyyah al-Kitab, 1983), 35. Lihat juga Muḥammad al-Nāsif, F̄̄ Tarbiyah wa Ta līm (Tunis: alSyarikah al-Tunisiyyah, 1981), 25. 
penglibatan yang berkesan terhadap masyarakat ${ }^{\mathbf{8}}$. Disamping itu, dapat juga disimpulkan bahawa remaja adalah aset penting dalam usaha menyediakan sumber manusia dan generasi masa depan yang akan menentukan kemajuan dan kemapanan pembangunan masyarakat serta negara ${ }^{9}$. Justeru, sebagai bakal peneraju dan pewaris bangsa, remaja bakal berhadapan dengan pelbagai cabaran dan persaingan yang hebat. Persiapan jati diri remaja adalah amat penting bagi menjamin kelestarian peranan mereka terhadap masyarakat dan negara.

Walau bagaimanapun, sesuai dengan pemaknaan remaja yang mengalami perubahan pesat dalam pelbagai aspek kehidupan, maka ada ketikanya apabila perubahan secara mendadak berlaku. Sering juga berlaku kekeliruan pada diri remaja dalam proses mendapat kematangan biologi dan sosial yang terjadi terhadap mereka, maka ia boleh menyebabkan para remaja dilanda masalah tekanan. Akibatnya, ada di antara remaja yang cuba mencari jalan keluar dengan kegiatan negatif serta melalaikan atas alasan mencari ketenangan ataupun juga untuk mencapai kepuasan diri. Antara perkara negatif tersebut ialah lari dari rumah ${ }^{10}$. Jumlah kehilangan remaja di negara ini bukan sahaja amat memeranjatkan tetapi sangat membimbangkan setiap ibu bapa dengan jumlah remaja hilang atau lari dari rumah berjumlah 6270 remaja sejak Januari 2004 hingga Mei 2007 dengan purata 216 orang sebulan atau sekitar 54 orang seminggu. Hal ini merupakan suatu angka

8 Jas Laile Suzana Jaafar, Psikologi Kanak-kanak dan Remaja (Selangor: Arah Publications, 2008), 209; Namun dalam Islam mempunyai penilaian yang tersendiri dalam menentukan tahap keremajaan seseorang iaitu bemula apabila seseorang itu telah mencapai tahap baligh pada usia 18 tahun. Lihat Muhammad 'Azmī 'Abd al-Salam Șāliḥ, Al-Ta'sil al-Islāmī li Ria'yāt alShabāb (Kaherah: Dār al-Șahwah, 1985), 28.

9 Bahagian Perancangan dan Penyelidikan Dasar Pendidikan, Kementerian Pendidikan Malaysia, Laporan Pengesahan Amalan Peraturan-Peraturan Displin Pelajar Peringkat Sekolah (Kuala Lumpur: Kementerian Pendidikan Malayasia, 1998).

10 Johari Alias, Menunaikan Kewajipan dan Tanggungjawab (Kuala Lumpur: Dewan Bahasa dan Pustaka, 1992), 45; Ramai remaja yang ingin bebas dari kongkongan ibu bapa untuk berdikari dan berbuat apa sahaja yang disukainya tetapi sebenarnya masih lagi memerlukan kepada pergantungan ibu bapa mereka. Lihat Mahmood Nazar Muhammad, Pengantar Psikologi: Satu Pengenalan Asas kepada Jiwa dan Tingkah Laku Manusia (Kuala Lumpur: Dewan Bahasa dan Pustaka, 1990), 219. 
yang agak besar yang seharusnya dibendung dan diatasi dengan serius. Jika tidak diatasi ia dapat merosakkan komuniti masyarakat serta dapat memberi impak yang negatif terhadap akhlak remaja yang boleh membawa mudarat kepada kekuatan sistem dan struktur ekonomi yang diamalkan oleh sesuatu masyarakat, komuniti mahupun negara.

Secara umumnya, remaja yang lari dari rumah adalah remaja yang meninggalkan rumah dengan serta merta tanpa memberitahu ibu bapa ke mana hala tujuan mereka. Dalam istilah bahasa Inggeris lari dari rumah disebut sebagai runaway. Lari dari rumah ialah satu tingkah laku atau perbuatan meninggalkan rumah tanpa restu daripada ibu bapa menuju ke satu tempat yang biasanya tidak diketahui oleh ahli keluarganya. Golongan remaja adalah merupakan golongan yang paling banyak dikaitkan dengan tingkah laku lari dari rumah ini, kebanyakan daripada mereka meninggalkan rumah dengan memasang niat tidak akan pulang semula ke rumah lagi. Sesetengah daripada golongan remaja tersebut biasanya akan kembali dalam jangka masa tertentu seperti dalam masa beberapa hari, beberapa minggu, beberapa bulan dan bertahun-tahun malahan ada juga yang tidak kembali langsung sehingga diklasifikasikan sebagai orang hilang.

Individu yang lari dari rumah adalah mereka yang berasa putus asa dan tidak gembira apabila berada di dalam rumah ${ }^{11}$. Daripada huraian tersebut dapat mengetahui bahawa terdapat beberapa faktor yang menyebabkan belia berasa putus asa dan tidak gembira ketika berada di dalam rumah, antaranya ialah dipengaruhi oleh faktor-faktor persekitaran. Jika ditinjau dari sudut bilangan kes pula, tingkah laku lari dari rumah ini amat membimbangkan dan menjadi semakin serius. Rangkaian Kebangsaan bagi Khidmat Belia misalnya telah membuat anggaran bahawa setiap tahun lebih kurang 1.3 juta remaja terlibat dengan kes meninggalkan rumah ${ }^{12}$. Jumlah tersebut membuktikan serta menunjukkan kes betapa seriusnya masalah sosial yang melibatkan golongan remaja ini.

11 John W Santrock, Life Span Development (New York: McGraw-Hill, 2007), 15 .

12 Kenneth J Neubeck \& Marie Alice Neubeck, Social Problems a Critical Approach (New York: Hill Companies,Inc, 1999), 21. 
Kajian telah menunjukkan terdapat pelbagai faktor pendorong kepada peningkatan isu ini, namun antara faktor pendorong utamanya ialah berpunca dari corak dan bentuk didikan institusi keluarga itu sendiri khususnya didikan ibu bapa ${ }^{13}$. Ini kerana peranan yang dimainkan oleh ibu bapa dalam mendidik anak-anak amat penting bagi membentuk personaliti anak-anak dari sudut spiritual, mental dan perilaku remaja sama ada menjurus kepada pembentukan jati diri positif ataupun negatif. Pendidikan yang diberikan kepada anak-anak perlulah meliputi segenap aspek meliputi soal akhlak, pergaulan, ilmu pengetahuan serta mempunyai sifat malu apabila melakukan kesalahan. Remaja yang didik dengan sifat tersebut akan menjadi dewasa dengan kesempurnaan akal. Nasihat-nasihat tentang dunia ini sebagai tempat menyediakan bekal di akhirat dan bukannya tempat memperturutkan hawa nafsu pasti meresap ke dalam jiwa mereka yang telah didik dengan baik ${ }^{14}$.

Oleh yang demikian, kertas kerja ini akan dimanfaatkan dengan isu pendidikan keibubapaan yang diterapkan daripada pemikiran tokoh terkenal pendidikan anak-anak, Abdullah Nasih Ulwan untuk membentuk sebuah "Model Pendidikan Keibubapaan Ulwan (MPIU)" dengan menjurusi perbincangan yang dibuat dalam kitab Tarbiyah al-Awlad kerana ia dilihat mempunyai elemen serta metode pendidikan melibatkan psikologi dan sosiologi yang boleh diandaikan menyeluruh bagi membantu membangunkan jiwa remaja ke arah yang lebih baik umumnya, dan dalam mengurangi gejala remaja lari dari rumah, khususnya.

\section{Remaja dan Psikologi}

Perkembangan fizikal, mental, psikologi dan spiritual adalah antara aspek penting pada peringkat remaja. Remaja perlulah dididik untuk menyayangi tubuh badan atau fizikal yang telah dianugerahkan kepada mereka agar terhindar dari penyakit yang disebabkan oleh faktor pemakanan, kurangnya aktiviti fizikal dan kepercayaan yang boleh menyebabkan individu merasakan dirinya tidak sihat seperti perasaan rendah diri terhadap bentuk tubuh,

${ }^{13}$ Hanif Zakaria \& Mohd Razali Md Nor, "Masalah Remaja Berpeleseran: Satu Kajian Kes di Kuala Lumpur" (Kertas Projek, Uitm Shah Alam,1993).

14 Abū Ḥāmid Muḥammad al-Ghazālī, Mukashafah al-Qulūb (Beirut: Dār alJayl, 1991), 370. 
kecantikan dan sebagainya ${ }^{15}$. Remaja juga merupakan golongan yang tersepit di antara dua situasi atau zaman transisi dari berperanan sebagai anak kecil yang bergantung kepada ibu bapa ke arah yang lebih berdikari dan mencapai kedewasaan ${ }^{16}$. Di samping itu, remaja juga dikatakan turut mengalami suatu perkembangan emosi yang pesat sehingga disebut oleh Kohlbergh Gilligan sebagai "kemuncak emosi" ${ }^{17}$ Manakala dalam pandangan Islam pula, perkembangan spiritual/kerohanian pada tempoh remaja adalah amat penting kerana pada masa inilah segala pendidikan asas Islam wajib diperkenalkan kepada mereka. Apa yang dimaksudkan dengan asas Islam di sini ialah ilmu tentang Syariat Islam yang merangkumi ilmu akidah (Iman), hukumhakam (Islam) dan akhlak (Ihsan).

Jika dilihat dari aspek perkembangan personaliti remaja, ianya amat berkait rapat dengan aspek tingkah laku mereka pada peringkat kanak-kanak. Perkembangan ini akan membawa kepada pembentukan harga diri dan identiti diri yang saling berkait dengan konsep kendiri dikenali sebagai imej kendiri ${ }^{18}$. Konsep kendiri penting bagi remaja kerana semasa mereka berada di era ini, mereka akan mengalami peningkatan kekuatan fizikal dan tahap autonomi. Justeru, sekiranya remaja terbentuk dengan memiliki konsep kendiri yang salah, maka ada ketikanya ia akan membahayakan diri mereka sendiri dan juga orang lain seperti bertingkah laku agresif, kerisauan, ketakutan, tiada keyakinan diri, tersisih dan sebagainya ${ }^{19}$. Namun, sekiranya konsep kendiri yang baik dapat dipupuk dan ditanam, maka remaja itu akan berkembang menjadi orang yang baik tingkah laku, berkeyakinan,

15 Goud Nelson \& Arkoff Abe, Psychology and Personal Growth, (USA: Allyn and Bacon, 1998), 58-60.

16 Cecil G. Helmen, Budaya Kesihatan dan Penyakit, terj. Hasyim Awang (Kuala Lumpur: Dewan Bahasa dan Pustaka, 1994), 30.

17 Kathleen M. White dan Joseph C. Speisman., Remaja, terj. Maznah Ismail (Kuala Lumpur: Dewan Bahasa dan Pustaka, 1984),

18 Harold D. Grotevant \& Catherine R. Cooper, Individuality and Connectedness in Adolescent Development (London: Routledge, 1998), 6; Habibah Elias \& Noran Fauziah Yaakub, Psikologi Personaliti (Kuala Lumpur: Dewan Bahasa dan Pustaka, 2006), 70.

19 Azizi Yahaya et al., Penyelewengan Tingkah Laku Remaja Punca \& Rawatan (Skudai: UTM, 2012), 217. 
tenang dan sebagainya ${ }^{20}$. Oleh yang demikian, konsep kendiri remaja boleh difahami sebagai keseluruhan persepsi mereka terhadap diri sendiri sama ada berbentuk deskriptif atau berupa penilaian secara kognitif. Atau ia boleh difahami sebagai proses penerimaan seseorang remaja terhadap diri sendiri di mana sekiranya remaja itu menganggap dirinya adalah positif, maka tingkah laku dan emosinya juga adalah positif, dan sebaliknya ${ }^{21}$.

Dalam Islam, konsep kendiri yang dibincangkan banyak melihat kepada sudut spiritual tanpa mengenepikan aspek fizikal dan lain-lainnya. Psikologi personaliti Islam adalah hasil kajian ilmu Islam yang berhubung dengan tingkah laku manusia. Ia berdasarkan kepada pendekatan psikologi terhadap hubungan manusia dengan Pencipta, manusia lain dan alam. Jika ditelusuri secara ringkas, psikologi personaliti Islam boleh dibahagikan kepada lima bahagian, pertama, mengenai ilmu Islam yang menggambarkan corak dan pola berfikir dalam psikologi personaliti. Keunikannya adalah dari aspek ontologi yang membicarakan ilmu falsafah atau metafizik yang berhubung kait dengan fitrah manusia, epistemologi yang mengetengahkan teori sumber ilmu khususnya berkaitan kajian kritis tentang kesahihan, kaedah dan skop sesuatu pengetahuan, dan aksiologi yang mendiskusi teori sesuatu nilai serta mengklasifikasikan apa yang baik untuk dilakukan dan sejauh mana keelokan kebaikan tersebut. Kedua, mengenai tingkah laku manusia yang dilihat memiliki citra dan keunikan tersendiri sesuai dengan apa yang terdapat pada pelakunya. Ketiga, berdasarkan pendekatan psikologi yang menggambarkan "apa" dan "bagaimana" tingkah laku manusia yang timbul dari jiwanya menurut pandangan Islam. Keempat, mengkaji tingkah laku manusia dan kaitannya dengan sesama manusia, alam dan Penciptanya. Manakala yang kelima adalah untuk meningkatkan kebahagiaan hidup di dunia dan akhirat. Secara keseluruhannya, psikologi personaliti Islam bukan sahaja mengindentifikasikan tingkah laku, malahan turut mengungkap bagaimana seharusnya manusia itu bertingkah laku. ${ }^{22}$ Justeru,

${ }^{20}$ Abū Ḥāmid Muḥammad al-Ghazālī, Ihyā' 'Ulūm al-Dīn (Beirut: Dār alMa'rifah, 1982), 3:3-5.

21 Azizi Yahaya,et.al., Penyelewengan, 220.

22 Dra. Netty Hartati, M.Si. et al., Islam dan Psikologi (Jakarta: PT RajaGrafindo Persada, 2004), 128. 
tingkah laku yang diharapkan adalah melandasi ajaran Islam yang sebenarnya.

Dalam membahaskan isu personaliti manusia khususnya remaja, al-Ghazālī menyatakan kendiri remaja terbentuk berdasarkan sifat kerohanian dan kejiwaan. Jiwa remaja atau manusia ini merangkumi unsur seperti al-qalb, al-ruh, al-nafs dan $a l$-'aql yang saling berhubungan bagi menentukan corak berfikir seseorang. Menurutnya, keempat-empat unsur tersebut sangat penting dan saling mempengaruhi kehidupan manusia. Ia dapat dilihat dari sudut fungsi unsur tersebut untuk melahirkan cara berfikir dan perasaan yang positif sekaligus dapat diterjemahkan dengan perilaku yang positif ${ }^{23}$.

Krisis ini akan timbul jika remaja keliru terhadap peranan dirinya yang sebenar dan bagaimanakah hidup yang seharusnya dilalui. $^{24}$ Pada peringkat ini akan berlaku kekeliruan pada diri seseorang remaja dalam proses untuk mendapatkan kematangan biologi, sosial, emosi, mental mahupun spiritual. Justeru, di sinilah ibu bapa perlu berperanan sewajarnya dalam memberi pendidikan sempurna terhadap anak-anak. Ini kerana pendidikan bukan sahaja dapat menghindarkan mereka daripada gejala negatif, malah dapat pula mengelak mereka daripada bahaya balasan neraka di akhirat kelak $^{25}$. Oleh yang demikian, pentingnya aspek perkembangan spiritual remaja diberi penekanan melalui pendidikan ilmu agama Islam di samping ilmu yang lain bagi meningkatkan keimanan, ketaqwaan, khawf, khashiyah atau takut kepada Allah daripada kemurkaan dan siksaanNya, serta timbul harapan untuk beroleh keampunan dan ganjaranNya ${ }^{26}$.

\section{Gejala Lari dari Rumah di Kalangan Remaja}

Walaupun kebanyakan remaja dapat melepasi zaman remaja dengan berjaya, namun terdapat juga sebilangan yang mengalami

23 Al-Ghazālī, Ihyā' 'Ulūm al-Dīn, 3-5.

24 Azlina Abu Bakar @ Mohd, Psikologi Personaliti Individu (Shah Alam: Karisma Publication Sdn. Bhd., 2005), 59.

25 Abdullah Nasih Ulwan, Pendidikan Anak-anak dalam Islam, terj. Abdullah Semait (Singapura: Pustaka Nasional, 1988), 1:424, Nor Azah Abdul Aziz, "Pengawalan Diri ke Atas Pelayaran Laman Web Pornografi pada Peringkat Remaja di Lembah Klang, Malaysia dari Sudut Psikospiritual Islam", (Tesis kedoktoran, Universiti Malaya, 2009), 131.

${ }^{26}$ Abdullah Nasih Ulwan, Pendidikan Anak-anak dalam Islam, 424. 
pelbagai masalah psikologi dan tingkah laku yang menggugat kehidupan remaja serta kehidupan masyarakat sekeliling. Antaranya ialah masalah remaja lari dari rumah. Gejala ini semakin meningkat dari hari ke hari sebagai mana yang sering dipaparkan dalam media massa dan perbincangan masyarakat. Remaja lari dari rumah secara umumnya dapat diistilahkan sebagai mereka yang berumur 18 tahun ke bawah dan telah meninggalkan rumah tanpa pengetahuan ibu bapa atau diabaikan oleh keluarga ${ }^{27}$. Mereka biasanya akan lari ke rumah sahabat baik, ke rumah saudara mara mereka, mengikut teman lelaki atau ke mana sahaja yang dirasakan wajar.

Kebimbangan mengenai isu remaja lari dari rumah boleh dibuktikan dengan peningkatan angka statistik yang telah dibuat oleh Polis Diraja Malaysia (PDRM). Catatan pada tahun 2010 menunjukkan peningkatan kes sebanyak 4,097 remaja yang membabitkan seawal usia 13 tahun hingga 17 tahun ${ }^{28}$. Angka ini bukan sahaja menunjukkan kuantiti, malah menunjukkan kes ini semakin serius dan perlu ditangani dengan segera. Antara faktor yang mendorong remaja untuk lari dari rumah ialah faktor keluarga. Kebiasaannya konflik dalam keluarga yang berlaku di dalam sesebuah rumah tangga akan memberi kesan yang mendalam kepada para remaja. Ibu bapa yang kurang pengetahuan dalam pendidikan keibubapaan akan menambahkan lagi bebanan kepada anak-anak mereka. Situasi tersebut akan menimbulkan tekanan emosi kepada jiwa yang akan menyebabkan mereka bertindak untuk meninggalkan rumah dan mencari kepuasan di luar rumah ${ }^{29}$.

Hasil kajian para sarjana juga jelas membuktikan terdapat hubungan antara didikan yang diterima, permasalahan dalam keluarga, tahap hubungan dan kawalan keluarga dengan prestasi anak-anak. Pola interaksi daya tindak dan pembentukan personaliti melalui pengalaman dalam suasana persekitaran kekeluargaan adalah suatu asas kepada interaksi dan dilihat sebagai langkah bagi

27 Akta kanak-kanak 2001; Adam, G. R., \& Gullota, T., Adolescent Life Experiences (California: Wad Sworth Inc., 1983), 421.

${ }^{28}$ Laman sesawang Utusan Online, dicapai 1 Mei 2013, http://www.utusan.com.my/utusan/Bicara_Agama/20121226/ba_01/Masalahmoral-remaja\#ixzz2S3Yh6or3

29 Mohammad Kamil Abd Majid, "Tanggungjawab Pendidikan Anak-Anak Remaja”, Majalah Pengasuh (Januari 1991), 36. 
menyelesaikan masalah anak-anak. ${ }^{30}$ Justeru, pendidikan dan kawalan ibu bapa terhadap anak-anak adalah sesuatu yang amat mustahak dan memerlukan penelitian semula daripada pihak ibu bapa sendiri mahu pun masyarakat.

\section{Model Pendidikan Keibubapaan Menurut Abdullah Nasih Ulwan}

Aspek dan isu pendidikan keibubapaan sudah lama diperkatakan serta dibincangkan di semua peringkat dalam masyarakat. Namun ianya masih lagi dibincangkan sehingga sekarang kerana ketidakselesaian permasalahan sosial yang semakin hari semakin meruncing. Institusi keluarga khususnya ibu bapa berhadapan dengan banyak tekanan dari sudut pendidikan anak-anak ini.

Secara umumnya keibubapaan adalah satu institusi yang dianggotai oleh individu yang berperanan memenuhi asas-asas keperluan yang harus disediakan untuk anak-anak membesar menjadi manusia dewasa. Hal ini juga, termasuklah asas-asas kepada keperluan emosi serta spiritual. Ikatan antara individu dalam institusi tersebut adalah ikatan perkahwinan yang sah di antara seorang suami dan isteri, kemudian hubungan keduaduanya akan menghasilkan kewujudan insan-insan baru secara biologikal. ${ }^{31}$ Dari sudut pandang Islam, institusi keibubapaan sememangnya satu institusi yang amat penting dan perlu diberikan perhatian khusus. Ini dapat dibuktikan dengan firman Allah yang menerangkan perjalanan kehidupan manusia di muka bumi bermaksud:

Wahai sekalian manusia! Bertakwalah kepada Tuhan kamu yang telah menjadikan kamu (bermula) dari diri yang satu (Adam), dan yang menjadikan daripada (Adam) itu pasangannya (isterinya - Hawa), dan juga yang membiakkan dari keduanya - zuriat keturunan - lelaki dan perempuan yang ramai. Dan bertakwalah kepada Allah yang kamu selalu meminta dengan menyebut-nyebut namaNya, serta peliharalah hubungan (silaturrahim) kaum kerabat; kerana

30 Sabitha Marican, "Penelitian Terhadap Remaja Lari dari Rumah: Punca-punca dan Strategi Penyelesaiannya" (Seminar Kebangsaan Gejala Sosial, Jitra, 1995), 1-18.

31 Harlina Halizah Haji Siraj, "Keibubapaan dalam Islam” (Seminar Keluarga Islam, Kemahiran Keibubapaan dan Cabaran Semasa, 11-12 Mei, 2004), 2. 
sesungguhnya Allah sentiasa memerhati (mengawas) kamu. (Surah al-Nisā' 4:1).

Oleh yang demikian, antara cabaran dalam isu pendidikan keibubapaan ialah kesediaan ibu bapa tersebut dalam mengendalikan tanggungjawab mereka untuk mengasuh dan mendidik anak-anak. Ini bermaksud ibu bapa berkenaan sudah bersedia dan merancang terlebih dahulu dengan apa yang harus dilakukan apabila menerima kelahiran anak masing-masing. Bersedia bererti ibu bapa sudah mempelajari dan menimba ilmu pengetahuan selengkap mungkin bagi tujuan mendidik anak-anak mereka. Dengan kata lain, ibu bapa harus mempunyai ilmu berkaitan pendidikan keibubapaan yang berteraskan syariat Islam. Tanpa ilmu ini, sesebuah institusi keluarga akan pincang dan akan menimbulkan banyak masalah terutama kepada anakanak. $^{32}$

Ahli psikologi berpandangan selain ilmu pengetahuan dan dimensi tingkah laku ibu bapa, elemen penting lain ialah yang melibatkan kombinasi secara keseluruhan dimensi yang ada, iaitu kombinasi emosi dan pengawalan ${ }^{33}$. Justeru, tiga model gaya keibubapaan telah diperkenalkan oleh Baumrind ${ }^{34}$ dan diteruskan dengan satu model lagi oleh Maccoby dan $\operatorname{Martin}^{35}$ iaitu autoritatif, permisif, autoritarian dan pengabaian. Secara ringkasnya, model autoritatif mencernakan gaya keibubapaan yang seimbang antara responsif dengan permintaan. Mereka bersikap mesra, terbuka dan prihatin serta demokratik terhadap anak-anak. Anak-anak diterangkan secara rasional mengenai disiplin dan hala tuju yang ditentukan dan mereka dibenarkan bebas untuk menentukan cita-cita dengan panduan dan bimbingan kedua ibu bapa. Gaya ini antara gaya terbaik kerana ia membolehkan anakanak mempunyai keyakinan dan kawalan diri, pada masa yang

32 Al-Ghazāli, Ihyā' 'Ulūm al-Dīn, 3-5; Syed Hassan Syed Ahmad al-Mashoor, "Cabaran Keibubapaan Anak Remaja dan Dewasa" (Seminar Keluarga Islam, Kemahiran Keibubapaan dan Cabaran Semasa, 11-12 Mei 2004),10.

33 Azizi Yahaya et.al., Penyelewengan, 165.

34 D Baumrind, "The Influence of Parenting Style on Adolescent Competence And Substance Use", Journal of Early Adolescence, 11, no.1 (1991), 56.

35 E.E. Maccoby, \& J.A. Martin, "Socialization in the Context of Family: Parentchild Interaction", dalam Handbook of Child Psychology, ed. E. M. Hertherington \& P. Mussen (New York: Wiley, 1983), 4:24. 
sama bebas dan tidak terlalu bergantung serta mampu pula membuat keputusan yang baik ${ }^{36}$.

Model gaya permisif pula menampakkan ibu bapa yang juga mesra dan terbuka, namun apabila melibatkan prihatin atau responsif, ia adalah amat tinggi. Selain itu, ibu bapa dengan gaya ini tidak mempunyai tuntutan terhadap anak-anak untuk memenuhi sasaran kerana terlalu bertolak ansur serta memberi kebebasan sehingga hampir kesemua kehendak anak dituruti. Gaya ini dilihat bertentangan dengan gaya autoritatif dan akan melahirkan anak yang tidak mempunyai arah tuju yang jelas, tiada pendirian dan kurang kasih sayang ${ }^{37}$. Gaya ketiga ialah autoritarian yang menampilkan gaya keibubapaan yang mempunyai tahap responsif atau prihatin yang rendah terhadap anak-anak, tetapi permintaan mereka amat tinggi sehingga meletakkan harapan terlalu tinggi dan tidak munasabah serta tidak mesra. Anak-anak hampir tidak langsung diberi kebebasan dan tolak ansur. Gaya ini akan melahirkan anak-anak yang sukar membuat keputusan betul dan tepat, tiada keyakinan diri, tidak bebas dan suka bergantung ${ }^{38}$. Manakala gaya terakhir ialah gaya pengabaian yang merujuki ibu bapa yang tidak mesra serta tidak responsif atau prihatin sama sekali terhadap anak-anak. Begitu juga mereka hampir tidak mempunyai permintaan, disiplin dan hala tuju terhadap anak-anak. Kebebasan diberikan sepenuhnya kepada anak-anak tanpa pengawalan sehingga menyebabkan mereka seperti tiada pedoman. Gaya ini akan melahirkan anakanak yang tidak stabil dari aspek emosi, tidak serasi dengan situasi dan keadaan, tidak bertanggungjawab dan sering tidak mematuhi $\operatorname{arahan}^{39}$.

Apabila merujuk kepada peranan kedua ibu bapa dalam mendidik anak-anak supaya dapat melahirkan remaja berkualiti serta cemerlang dari sudut agama, akhlak, intelek, budaya dan

${ }^{36}$ D. Baumrind, "The influence of Parenting Style on Adolescent Competence and Substance Use", Journal of Early Adolescence, 11, 1 (1991); 62-63); Azizi Yahaya et.al., Penyelewengan, 166-168.

37 D. Baumrind, "The Influence of Parenting Style on Adolescent Competence and Substance use", 168-170.

38 D. Baumrind, "The Influence of Parenting Style on Adolescent Competence and Substance use", 168-169

39 D. Baumrind, "The Influence of Parenting Style on Adolescent Competence and Substance use", 62-63. 
sosial. Maka tidak cukup bagi sebuah keluarga Muslim untuk hanya mengguna pakai gaya keibubapaan yang diutarakan Baumrind, Maccoby dan Martin khususnya gaya terbaik iaitu autoritatif bagi menangani isu remaja lari dari rumah. Justeru, pengkaji mencadangkan satu model pendidikan keibubapaan Ulwan (selepas ini akan dikenali sebagai MPIU) berteraskan kitab Tarbiyah al-Awlad oleh Abdullah Nasih Ulwan dengan melihat kepada punca fenomena ini berlaku adalah daripada kesan gaya keibubapaan itu sendiri.

Dalam perbincangan kitab Tarbiyah al-Awlad, Abdullah Nasih Ulwan telah menghuraikan dua sudut pendekatan iaitu unsur spiritual ${ }^{40}$ dan juga fizikal. ${ }^{41}$ Oleh yang demikian, artikel ini hanya akan membahaskan satu daripada keduanya iaitu Pendidikan dari sudut spiritual.

\section{Pendidikan 1: Pendidikan dari Sudut Spiritual}

Pendidikan spiritual ini boleh dibahagikan kepada empat bentuk iaitu pendidikan keimanan, moral, rohani dan mental. Antara aspek-aspek yang terangkum dalam keempat-empat bentuk tersebut adalah seperti berikut:

\section{Pendidikan Keimanan}

Bagi mengikat diri anak-anak dengan kebaikan, maka MPIU mencadangkan setiap anak perlu diterapkan dengan unsur keimanan ini sejak kecil lagi. Ia boleh dilakukan dengan penerapan unsur-unsur berikut:

\begin{tabular}{|c|c|c|c|}
\hline & \multicolumn{3}{|r|}{ Unsur } \\
\hline $\mathrm{K}$ & & & o Mengenal kekuasan serta ciptaan Allah \\
\hline $\mathrm{e}$ & & & SWT. \\
\hline $\mathrm{i}$ & k & & Cara: Memikirkan tentang ciptaan langit \\
\hline $\mathrm{m}$ & 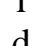 & kepada & dan bumi. \\
\hline $\mathrm{a}$ & $\mathrm{a}$ & Allah & o Menanam roh khusyuk, takwa dan \\
\hline $\mathrm{n}$ & $a^{a}$ & & perhambaan kepada Allah. \\
\hline $\mathrm{a}$ & & & $\begin{array}{l}\text { Cara: Mendidik sejak kecil lagi supaya } \\
\text { dapat khusyuk dalam solat dan merasa }\end{array}$ \\
\hline
\end{tabular}

40 Abdullah Nasih Ulwan, Pendidikan Anak-anak dalam Islam, 169-246 \& 299422.

41 Abdullah Nasih Ulwan, Pendidikan Anak-anak dalam Islam, 247-259 \& 423579. 


\begin{tabular}{|c|c|c|c|}
\hline \multirow{4}{*}{$\begin{array}{l}\mathrm{K} \\
\mathrm{e} \\
\mathrm{i} \\
\mathrm{m} \\
\mathrm{a} \\
\mathrm{n} \\
\mathrm{a} \\
\mathrm{n}\end{array}$} & \multirow{4}{*}{$d$} & & $\begin{array}{l}\text { "sedih" ketika membaca al-Qur'an. } \\
\text { o Mendidik jiwa supaya memiliki perasaan } \\
\text { "sentiasa ingatkan Allah" dalam segala } \\
\text { gerak geri. } \\
\text { Cara: } \\
\text { i. Membiasakan untuk mengingati Allah } \\
\text { ketika sedang berbuat sesuatu dan } \\
\text { mengajar supaya bercakap dengan } \\
\text { ikhlas [kepada Allah]. } \\
\text { ii. Membiasakan untuk mengingati Allah } \\
\text { ketika berfikir; berfikir perkara yang } \\
\text { boleh mendekatkan diri kepada Allah } \\
\text { serta berusaha meneladani rasul dan } \\
\text { nabiNya. } \\
\text { iii. Membiasakan untuk mengingati Allah } \\
\text { pada perasaan dan hati dengan } \\
\text { membersihkan hati dari sifat-sifat } \\
\text { mazmumah. }\end{array}$ \\
\hline & & $\begin{array}{c}\text { Beriman } \\
\text { kepada } \\
\text { Malaikat }\end{array}$ & $\begin{array}{l}\text { O Menanam keyakinan adanya persoalan } \\
\text { kubur oleh malaikat. } \\
\text { Cara: } \\
\text { i. Menerang dan menceritakan perkara } \\
\text { berkaitan persoalan kubur. } \\
\text { ii. Menerangkan malaikat Raqib dan Atid } \\
\text { tidak pernah meninggalkan manusia } \\
\text { walau sesaat untuk mencatat perbuatan } \\
\text { baik dan jahat yang dilakukan. }\end{array}$ \\
\hline & & $\begin{array}{c}\text { Beriman } \\
\text { kepada } \\
\text { Kitab }\end{array}$ & $\begin{array}{l}\text { O Membiasakan diri anak-anak dengan } \\
\text { membaca al-Qur'an. } \\
\text { Cara: } \\
\text { i. Mengajak membaca al-Qur'an bersama } \\
\text { atau menghantar mengaji kepada guru } \\
\text { agama. } \\
\text { ii. Mengajar supaya memahami isi } \\
\text { kandungan al-Qur'an. }\end{array}$ \\
\hline & & $\begin{array}{c}\text { Beriman } \\
\text { kepada } \\
\text { Nabi }\end{array}$ & $\begin{array}{l}\text { O Mendidik supaya mencintai Rasulullah } \\
\text { serta keluarga Baginda. } \\
\text { Cara: } \\
\text { i. Mengajarkan hal-hal peperangan }\end{array}$ \\
\hline
\end{tabular}




\begin{tabular}{|c|c|c|c|}
\hline $\mathrm{K}$ & & & $\begin{array}{l}\text { Rasulullah dan perjalanan para sahabat } \\
\text { serta tokoh-tokoh Islam. } \\
\text { ii. Menggalakkan selawat kepada } \\
\text { Rasulullah dan keluarga setiap masa. }\end{array}$ \\
\hline $\begin{array}{c}\mathrm{e} \\
\mathrm{i} \\
\mathrm{m} \\
\mathrm{a} \\
\mathrm{n} \\
\mathrm{a} \\
\mathrm{n}\end{array}$ & $\begin{array}{c}\mathrm{A} \\
\mathrm{k} \\
\mathrm{i} \\
\mathrm{d} \\
\mathrm{a} \\
\mathrm{h}\end{array}$ & $\begin{array}{l}\text { Beriman } \\
\text { kepada } \\
\text { Perkara } \\
\text { Sam 'iyyat } \\
\text { (Akhirat } \\
\text { dan } \\
\text { Takdir) }\end{array}$ & $\begin{array}{l}\text { O Menanam keyakinan terhadap seksaan } \\
\text { kubur, hari kebangkitan, hisab, syurga, } \\
\text { neraka dan perkara ghaib lain. } \\
\text { Cara: } \\
\text { i. Menerang dan menceritakan perkara } \\
\text { berkenaan al-sam iyyat. } \\
\text { ii. Menanam rasa gerun dan takut kepada } \\
\text { balasan buruk serta menanam rasa } \\
\text { rindu untuk mendapat balasan baik di } \\
\text { akhirat nanti. }\end{array}$ \\
\hline & $\begin{array}{l}\mathrm{R} \\
\mathrm{u} \\
\mathrm{k} \\
\mathrm{u} \\
\mathrm{n}\end{array}$ & $\begin{array}{c}\text { o Memula } \\
\text { seawal n } \\
\text { Cara: } \\
\text { i. Menga } \\
\text { ii. Mene } \\
\text { iii. Mens } \\
\text { menci } \\
\text { yang o } \\
\text { o Mendiril } \\
\text { Cara: } \\
\text { i. Menyu } \\
\text { ii. Meng } \\
\text { iii. Mem } \\
\text { atau d } \\
\text { iv. Mem } \\
\text { sudah } \\
\text { o Melakuk } \\
\text { Cara: } \\
\text { i. Melati } \\
\text { ii. Mene } \\
\text { iii. Mem } \\
\text { sudah } \\
\text { o Menunai } \\
\text { Cara: } \\
\text { i. Ibu ba }\end{array}$ & $\begin{array}{l}\text { kan pengenalan dengan kalimah syahadah } \\
\text { nungkin. } \\
\text { ajar supaya dihafal kalimah syahadah. } \\
\text { rangkan maknanya. } \\
\text { gajak supaya meyakini kewujudan Allah dan } \\
\text { intai Rasulullah SAW dengan membuat apa } \\
\text { disuruh dan meninggal apa yang dilarang. } \\
\text { kan solat sejak berusia } 7 \text { tahun. } \\
\text { uruh mendirikan solat. } \\
\text { ajar bacaan dalam solat supaya dapat dihafal. } \\
\text { biasakan solat berjemaah sama ada di masjid } \\
\text { i rumah. } \\
\text { narahi atau menghukum apabila anak yang } \\
\text { baligh enggan bersolat. } \\
\text { can ibadah puasa. } \\
\text { h berpuasa seawal mungkin. } \\
\text { rangkan sebab puasa disyariatkan. } \\
\text { narahi atau menghukum apabila anak yang } \\
\text { baligh enggan berpuasa. } \\
\text { ikan zakat. }\end{array}$ \\
\hline
\end{tabular}




\begin{tabular}{|c|c|}
\hline $\begin{array}{l}\mathrm{R} \\
\mathrm{u} \\
\mathrm{k} \\
\mathrm{u} \\
\mathrm{n}\end{array}$ & $\begin{array}{l}\text { anak. } \\
\text { ii. Menerangkan sebab disyariatkan dan cara } \\
\text { menunaikan zakat. } \\
\text { iii. Sentiasa mengingatkan kewajipan menunaikan } \\
\text { zakat. } \\
\text { O Mengerjakan haji ke Mekah jika mampu. } \\
\text { Cara: } \\
\text { i. Menjelaskan kewajipan menunaikan haji sekurang- } \\
\text { kurangnya sekali seumur hidup apabila mampu. } \\
\text { ii. Sentiasa menggalakkan supaya menabung dari } \\
\text { awal untuk menunaikan haji. } \\
\text { Kesan: Dapat memberikan kesedaran kepada anak- } \\
\text { anak sejak kecil lagi dalam melaksanakan } \\
\text { suruhanNya serta dengan mengerjakan ibadah-ibadah } \\
\text { ini dapat menyucikan hati dan jiwa, memberi } \\
\text { kesihatan badan serta dapat mendidik akhlak, } \\
\text { perbuatan dan perkataan. }\end{array}$ \\
\hline $\begin{array}{l}S \\
\mathrm{y} \\
\mathrm{a} \\
\mathrm{r} \\
\mathrm{i} \\
\mathrm{a} \\
\mathrm{t}\end{array}$ & $\begin{array}{l}\text { O Mengajar dan mengenalkan pada usia yang berakal } \\
\text { (mumayyiz) dengan hukum halal dan haram, } \\
\text { antaranya: } \\
\text { - Makan minum } \\
\text { - Pakaian } \\
\text { - Sebagainya } \\
\text { Kesan: Memberi kesedaran kepada anak sejak kecil } \\
\text { dengan mengerjakan perintah-perintah Allah dan } \\
\text { membiasakannya dengan mentaati segala } \\
\text { perintahNya dan menjauhi segala laranganNya. }\end{array}$ \\
\hline
\end{tabular}

Sekiranya ibu bapa dapat mendidik anak-anak sedari kecil berdasarkan kerangka di atas, maka anak-anak akan terikat kuat dengan ajaran Islam. Hati yang dipenuhi keimanan dan pemahaman mengenai tanggungjawab ibadah dan halal haramnya sesuatu perbuatan akan menghindari dari melakukan sesuatu perkara yang tidak disukai kedua ibu bapa atau yang boleh menimbulkan keresahan dan kesedihan mereka seperti melarikan diri dari rumah. Pada ketika anak-anak menghadapi masalah atau ketidakpuasan hati terhadap diri mahu pun keluarga, maka mereka yang terikat hatinya dengan keimanan dan keislaman ini akan mengambil jalan berbincang untuk menyelesaikannya dan bukannya dengan melarikan diri (escapism) ke arah suatu hala tuju 
yang tidak tentu arah. Selain itu, MPIU mengemukakan komponen seterusnya iaitu pendidikan moral.

\section{Moral}

Menurut Abdullah Nasih Ulwan, Pendidikan moral ialah sekumpulan prinsip-prinsip akhlak serta budi luhur yang perlu dilengkapkan ke dalam jiwa anak-anak. Ianya perlu dilazimkan sejak usia tamyiz anak tersebut sehingga mereka dewasa. Antara yang ditekankan dalam pendidikan moral ini ialah:

\begin{tabular}{|c|c|}
\hline & U115ит \\
\hline $\begin{array}{c}\mathrm{M} \\
\mathrm{o} \\
\mathrm{r} \\
\mathrm{a}\end{array}$ & $\begin{array}{l}\text { O Membesar serta mendidik anak atas dasar takutkan Allah, } \\
\text { sentiasa bergantung kepada Allah serta redha dengan } \\
\text { segala ketentuanNya. } \\
\text { Cara: } \\
\text { i. Menerang dan mengajar mengenai kebesaran, } \\
\text { keagungan, kemurkaan, kerahmatan, kemurahan Allah } \\
\text { dan sebagainya supaya dapat memahami bahawa } \\
\text { manusia hanyalah makhluk ciptaanNya dan Allah } \\
\text { adalah Pencipta. } \\
\text { ii. Mengajar dan mengingatkan tentang ketentuanNya } \\
\text { yang azali supaya dapat meredai apa sahaja yang } \\
\text { berlaku terhadap diri. Namun menasihat dan } \\
\text { menggalakkan supaya sentiasa berusaha, berdoa dan } \\
\text { bertawakal untuk mendapatkan sesuatu yang terbaik } \\
\text { dalam kehidupan. } \\
\text { Kesan: Hasilnya akan tumbuh secara semula jadi perasaan } \\
\text { serta akhlak yang mulia kerana dipengaruhi oleh elemen- } \\
\text { elemen agama seperti takutkan Allah , kebergantungan } \\
\text { sepenuhnya kepada Allah dan sebagainya. }\end{array}$ \\
\hline & $\begin{array}{l}\text { o Membiasakan anak dengan sifat-sifat mahmudah seperti: } \\
\text { - Berkata benar } \\
\text { - Amanah } \\
\text { - Lurus perjalanan } \\
\text { - Suka melebihkan orang lain } \\
\text { - Suka membantu orang susah } \\
\text { - Menghormati orang tua } \\
\text { - Bersedia menerima tetamu } \\
\text { - Berbuat baik kepada jiran } \\
\text { - Bersifat kasih sayang sesama manusia }\end{array}$ \\
\hline
\end{tabular}




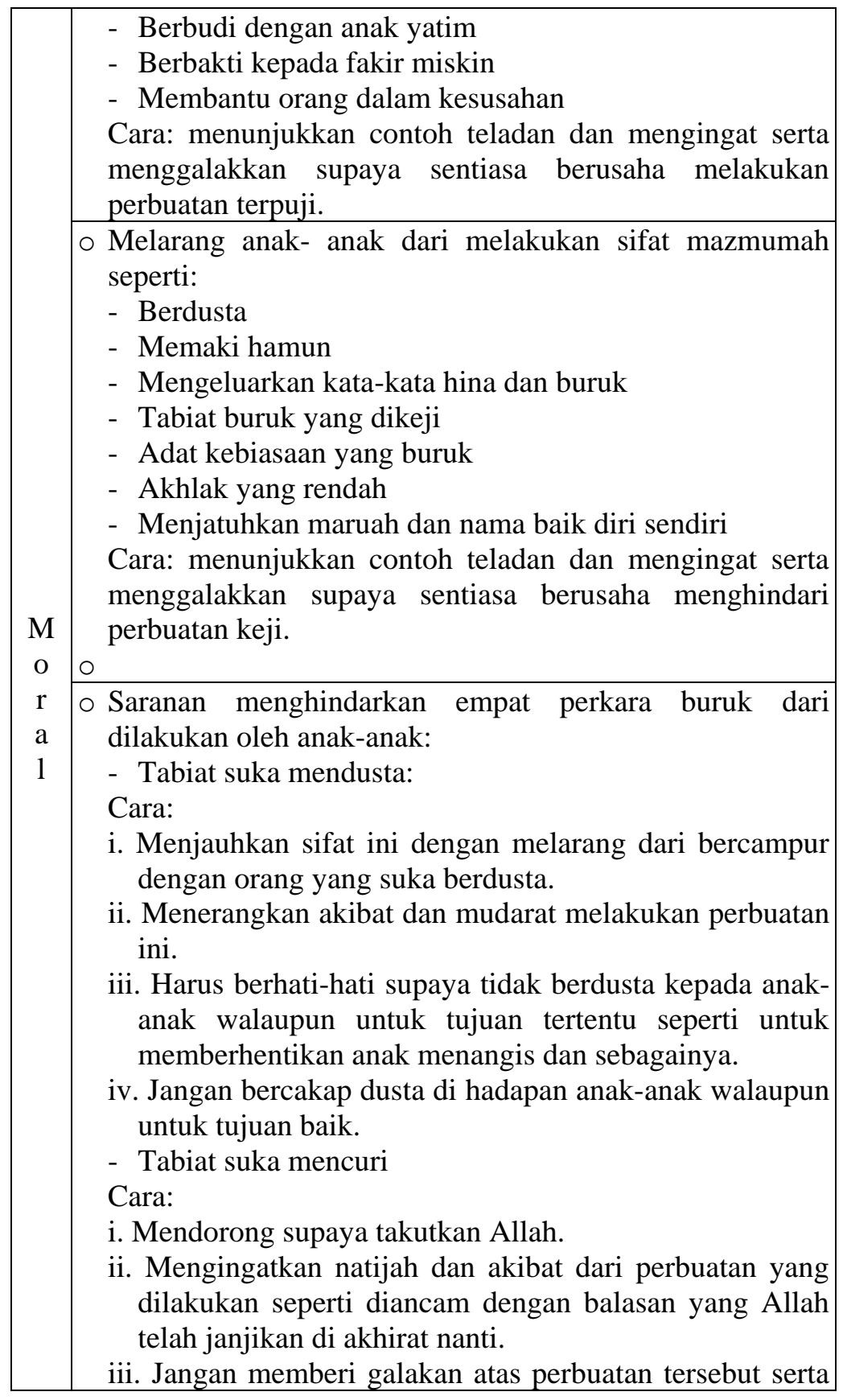




\begin{tabular}{|l|l|}
\hline & menyoal siasat secara terperinci jika terdapat perkara \\
& yang diragui. \\
& Cara: \\
& Tabiat suka mencaci dan memaki \\
& keji. \\
ii. Menghindarkan anak-anak dari terlibat dengan orang \\
yang rosak akhlaknya. \\
iii. Harus memberi pendedahan mengenai natijah dan \\
m \\
balasan kesan atas perbuatannya itu. \\
iv. Harus mengajar dengan mendatangkan hadis \\
r Rasulullah yang mengancam perbuatan keji tersebut. \\
r \\
a Mendidik dengan akhlak yang terpuji sejak mereka \\
kecil lagi. \\
- Tabiat suka meniru dan menyeleweng \\
Cara: \\
i. Larang dari meniru budaya barat yang membawa \\
kerosakan. \\
ii. Tegah dari tenggelam dalam kemewahan seperti \\
melampaui batas serta berlebih-lebihan dengan \\
kemewahan. \\
iii. Larang dari mendengar muzik serta nyanyian yang \\
membawa kepada kelalaian. \\
iv. Tegah anak lelaki dari menyerupai perempuan dan \\
perempuan menyerupai lelaki. \\
v. Larang pendedahan aurat, kebebasan, percampuran \\
yang liar, serta melihat perkara yang diharamkan.
\end{tabular}

Pendidikan moral sebegini dengan disertai pendidikan keimanan dan pengibadatan tadi akan mengikat anak-anak daripada berbuat perkara keji atau terlibat dengan masalah sosial. Tegahan berkelakuan buruk, malah melazimi diri mereka dengan tingkah laku terpuji disertai larangan dan tegahan daripada kedua ibu bapa akan membantu anak-anak membesar dalam suasana persekitaran yang sihat dan murni. Justeru ketegasan, keprihatinan, kasih sayang dan rasa tanggungjawab yang menebal dalam diri kedua ibu bapa akan membantu melestarikan lagi usaha pendidikan ini. Justeru, anak-anak yang tidak bebas lepas bersama rakan-rakan yang rosak akan tidak terpengaruh untuk melakukan sesuatu yang tidak disukai kedua ibu bapa. Dengan gaya kawalan 
dan kemesraan yang ditunjukkan kedua ibu bapa, anak-anak yang menghadapi masalah atau gejolak perasaan akan kembali ke pangkuan ibu bapa bagi membantu menyelesaikan apa yang dihadapi oleh mereka. Pendidikan gaya MPIU diperkukuhkan lagi dengan pendidikan rohani.

\section{Rohani}

Pendidikan rohani ialah mendidik anak-anak sejak dari kecil sehingga dewasa dengan keberanian, berkata benar, tidak pengecut, suka berbuat baik kepada orang lain, dapat mengawal diri dari bersifat marah dan melengkapkan diri dengan sifat-sifat mulia secara mutlak sama ada berbentuk fizikal atau rohani. Kedua ibu bapa wajib mendidik anak-anak supaya menjauhkan diri dari segala gejala yang boleh menyentuh kehormatan, keyakinan dan menghancurkan keperibadiannya antaranya ialah:

\begin{tabular}{|c|c|c|}
\hline & Unsur & Cara \\
\hline $\begin{array}{l}\mathrm{P} \\
\mathrm{e} \\
\mathrm{n} \\
\mathrm{d} \\
\mathrm{i} \\
\mathrm{d} \\
\mathrm{i} \\
\mathrm{k}\end{array}$ & \begin{tabular}{|l|} 
o Tabiat Malu \\
- Malu berjumpa \\
dengan \\
masyarakat \\
sekeliling
\end{tabular} & $\begin{array}{l}\text { Harus membiasakan untuk } \\
\text { bercampur dengan masyarakat } \\
\text { sekeliling secara terkawal. } \\
\text { O Mendidik untuk berani bergaul, } \\
\text { tidak pengecut dan tidak segan } \\
\text { silu. } \\
\text { O Membiasakan untuk bertindak } \\
\text { berani kepada perkara yang } \\
\text { benar. } \\
\text { Harus membiasakan anak-anak } \\
\text { menghadiri majlis orang ramai. }\end{array}$ \\
\hline $\begin{array}{l}\mathrm{R} \\
\mathrm{o} \\
\mathrm{h} \\
\mathrm{a} \\
\mathrm{n} \\
\mathrm{i}\end{array}$ & o Tabiat Takut & $\begin{array}{l}\text { Mendidik dari kecil lagi untuk } \\
\text { beriman kepada Allah., beribadah } \\
\text { kepada Allah serta penyerahan } \\
\text { diri kepada Allah. } \\
\text { O Memberi kebebasan untuk } \\
\text { bertindak, memikul semua } \\
\text { tanggungjawab } \\
\text { melaksanakan tiap-tiap perkara } \\
\text { menurut tahap perkembangannya. } \\
\text { O Jangan sesekali menakut- } \\
\text { nakutkan dengan perkara yang } \\
\text { tahyul dan berunsur khurafat. } \\
\end{array}$ \\
\hline
\end{tabular}




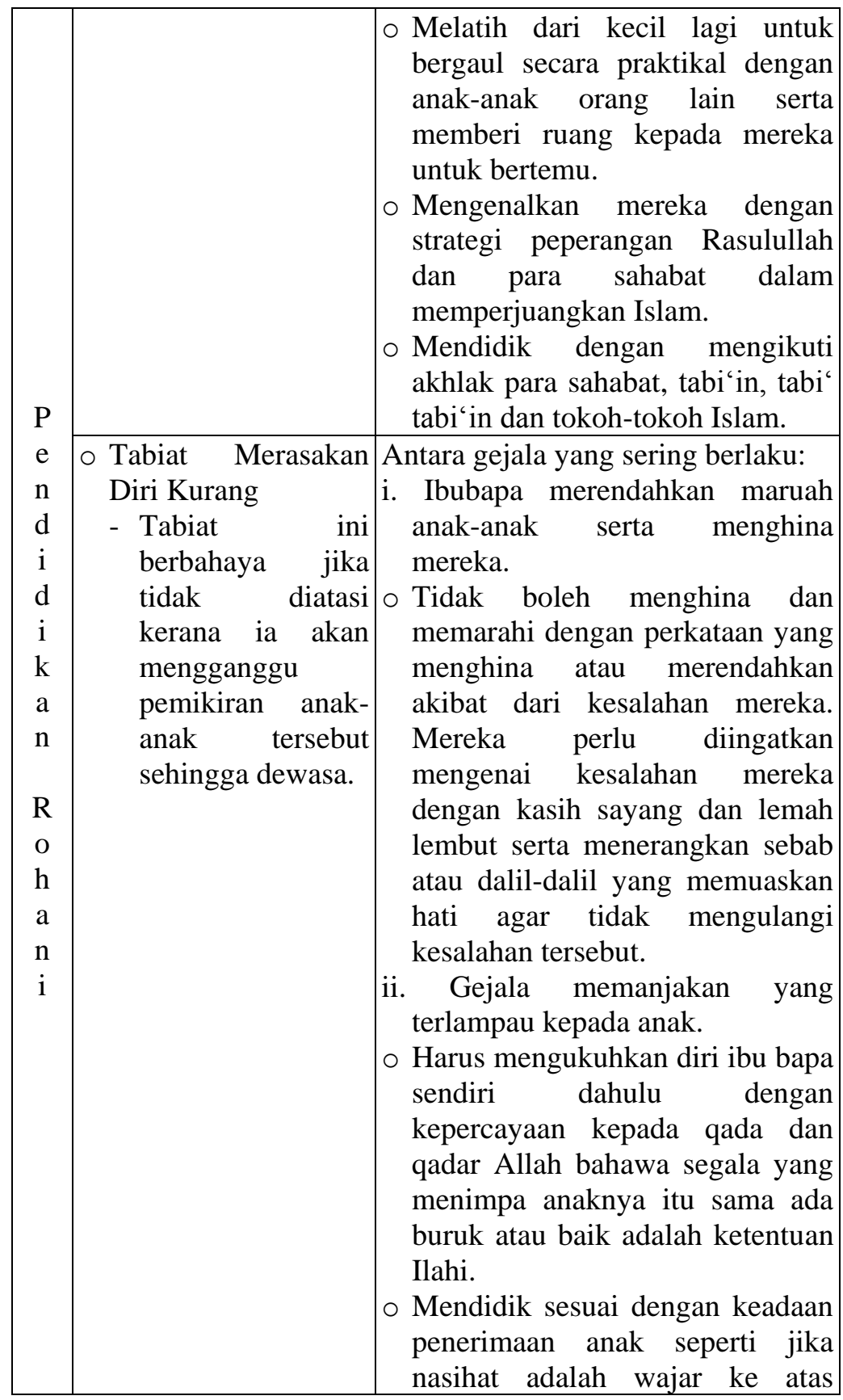




\begin{tabular}{|c|c|c|}
\hline $\begin{array}{l}\mathrm{P} \\
\mathrm{e} \\
\mathrm{n} \\
\mathrm{d} \\
\mathrm{i} \\
\mathrm{d} \\
\mathrm{i} \\
\mathrm{k} \\
\mathrm{a} \\
\mathrm{n}\end{array}$ & \begin{tabular}{|l} 
o Tabiat Dengki \\
- Tabiat ini ialah \\
yang \\
mengharapkan \\
tercabutnya \\
nikmat dari orang \\
lain. Antara sebab \\
tercetusnya \\
perasaan ini di \\
kalangan anak \\
ialah: \\
i. Kebimbangan anak \\
terhadap hilangnya \\
perhatian serta kasih \\
sayang sewaktu \\
mendapat kelahiran \\
baru. \\
ii. Perbandingan antara \\
anak-anak yang lain.
\end{tabular} & 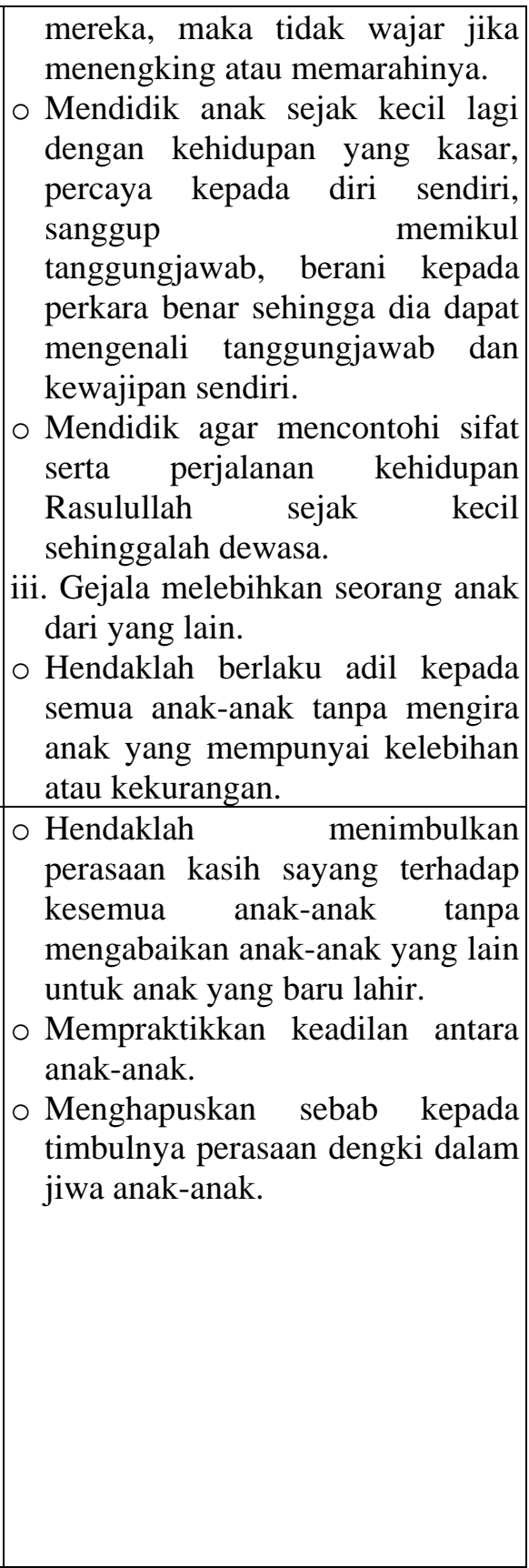 \\
\hline
\end{tabular}




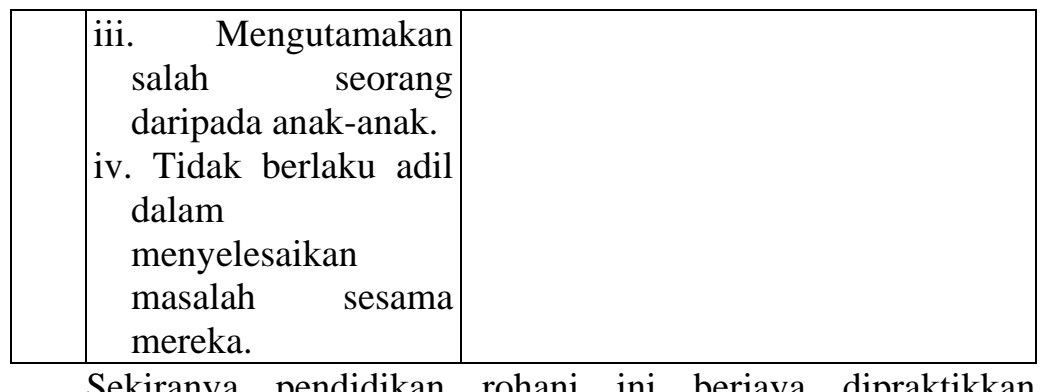

Sekiranya pendidikan rohani ini berjaya dipraktikkan bersama dengan pendidikan keimanan, pengibadatan dan moral, maka anak-anak yang membesar akan merasa dihargai, disayangi dan diberi perhatian sewajarnya oleh ibu bapa. Justeru, gejala lari dari rumah kerana ketidakpuasan hati, atau mencari kedamaian di luar, mahu pun terpengaruh dengan ajakan dan pujukan kawan atau teman tidak lagi timbul. Pada pandangan mereka, kehidupan yang disediakan di rumah adalah jauh lebih baik dan membahagiakan. Apatah lagi MPIU ini turut menyediakan model pendidikan mental sebagai pelengkap kepada pendidikan ini.

\section{Mental}

Pendidikan mental atau pendidikan akal adalah untuk membentuk pemikiran anak-anak dengan segala yang bermanfaat dari ilmu syariat, ilmu pengetahuan moden serta ilmu kesedaran yang bertamadun. Pendidikan ini harus diasah sejak kecil sehingga mereka berfikir secara matang. Hal ini kerana, pendidikan mental ini penting sebagai penyedaran, pembelajaran dan pengajaran kepada anak-anak tersebut. Oleh yang demikian, MPIU ini menggariskan tiga perkara utama yang perlu ditekankan oleh ibubapa dalam memberi pendidikan mental iaitu:

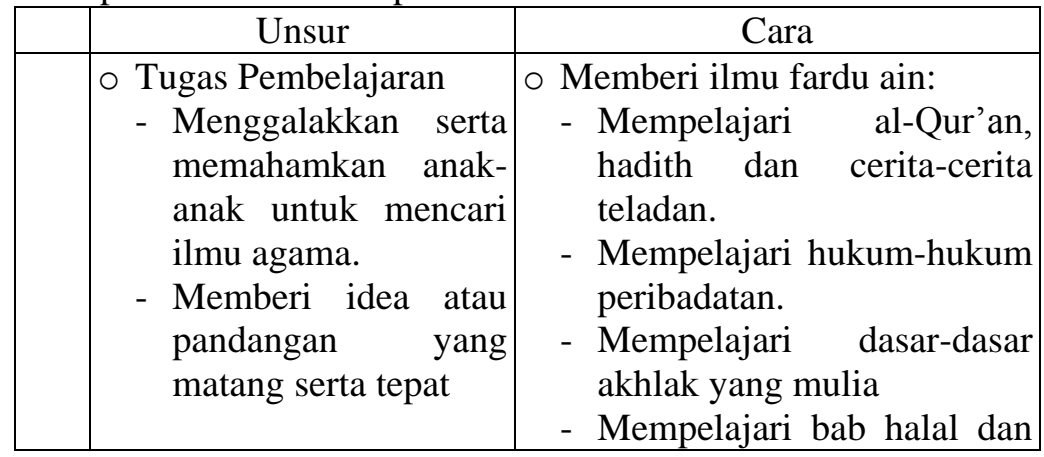




\begin{tabular}{|c|c|}
\hline & \begin{tabular}{|l} 
haram. \\
- Mempelajari ilmu asas \\
kesihatan. \\
o Memberi didikan ilmu fardu \\
kifayah: \\
- Ilmu pertanian \\
- Ilmu perindustrian \\
- Ilmu perniagaan \\
- Ilmu kedoktoran dan lain- \\
lain.
\end{tabular} \\
\hline \begin{tabular}{|lr} 
O Tanggungjawab \\
kesedaran mental iaitu \\
kesedaran & yang \\
menghubungkan anak \\
mengenai: & \\
- Islam dalam urusan \\
keduniaan & dan \\
kedaulatan. & \\
- Kebudayaan Islam \\
secara umum dari \\
segi kerohanian dan \\
pemikirannya. \\
- Pertalian dengan \\
gerakan dakwah \\
Islamiah dari segi \\
tenaga dan semangat. \\
Wajib mengenalkan \\
anak dengan beberapa \\
hakikat berikut: \\
- Kesyumulan Islam \\
dan kesesuaiannya \\
dengan semua masa, \\
zaman dan tempat. \\
- Pegangan terhadap \\
Islam serta \\
pelaksanaannya \\
dalam perundangan \\
menurut al-Qur'an. \\
- Pendedahan
\end{tabular} & $\begin{array}{l}\text { Untuk } \\
\text { tanggungjawab ini dalam jiwa } \\
\text { anak-anak, ibu bapa seharusnya: } \\
\text { o Mengajar tentang hakikat } \\
\text { Islam, dasar Islam serta Islam } \\
\text { merupakan agama yang } \\
\text { mutlak. } \\
\text { O Mengajar bahawa Islam } \\
\text { adalah agama yang mulia, al- } \\
\text { Qur'an sebagai panduan dan } \\
\text { Rasul sebagai teladan. } \\
\text { O Menerangkan rancangan jahat } \\
\text { musuh Islam } \\
\text { memusnahkan Islam. } \\
\text { O Wajib } \\
\text { kebudayaan Islam bukannya } \\
\text { kebudayaan barat. } \\
\text { O Menyerahkan anak sekiranya } \\
\text { perlu kepada pengasuh atau } \\
\text { penjaga yang faham Islam } \\
\text { serta syariatNya. } \\
\text { O Menghubungkan anak dengan } \\
\text { orang alim yang mengajar } \\
\text { mereka tentang Islam serta } \\
\text { syariatnya. } \\
\text { O Wajib memilih } \\
\text { menyaring bahan bacaan anak } \\
\text { sesuai dengan Islam dan } \\
\text { peringkat umurnya. }\end{array}$ \\
\hline
\end{tabular}




\begin{tabular}{|c|c|}
\hline \begin{tabular}{lr}
\multicolumn{3}{l}{ mengenai } \\
kebudayaan Islam. \\
- & Mengenalkan anak \\
mengenai sejarah \\
Islam yang dipimpin \\
oleh $\quad$ Rasulullah \\
bukannya & zaman \\
kepimpinan Abu & Abul, Abu Lahab \\
Jahal, & sebagainya.
\end{tabular} & $\begin{array}{l}\text { O Haruslah memilih rakan yang } \\
\text { baik serta yang mendorong } \\
\text { kepada kebaikan. }\end{array}$ \\
\hline 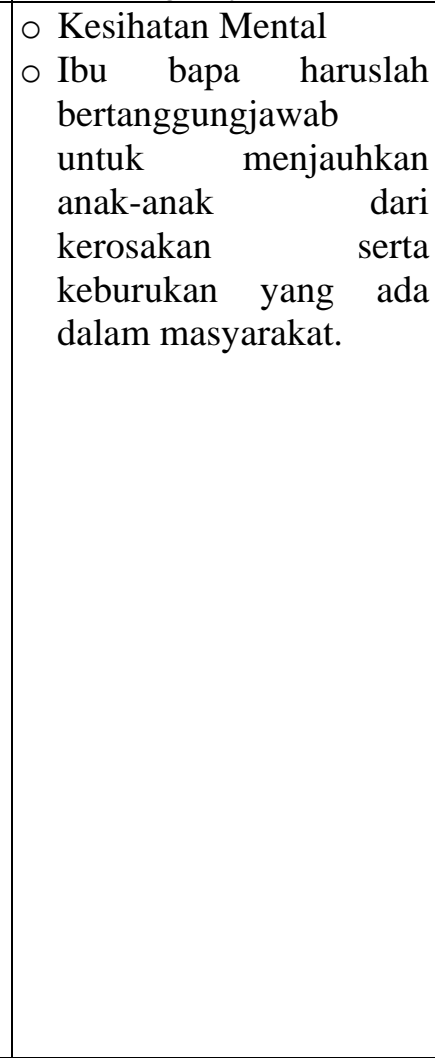 & $\begin{array}{l}\text { Ibu bapa perlu menjauhkan } \\
\text { anak-anak mereka dari: } \\
\text { o Minuman arak dan yang } \\
\text { memabukkan kerana akan } \\
\text { membahayakan kesihatan dan } \\
\text { membawa kepada penyakit } \\
\text { gila. } \\
\text { o Sikap yang membawa kepada } \\
\text { zina dan perbuatan zina, serta } \\
\text { segala penyakit yang berkaitan } \\
\text { dengan salah laku menurut } \\
\text { syarak kerana ia akan } \\
\text { melemahkan ingatan, kelesuan } \\
\text { dan penyakit otak. } \\
\text { Merokok dan mengambil } \\
\text { dadah kerana ia memberi } \\
\text { kesan sampingan yang buruk } \\
\text { pada otak, ingatan, organ serta } \\
\text { melemahkan fikiran. } \\
\text { Bahaya menaikkan nafsu seks } \\
\text { kerana dapat membantutkan } \\
\text { tugas akal, menyebabkan } \\
\text { gangguan mental, dan } \\
\text { membuang masa. }\end{array}$ \\
\hline
\end{tabular}

Secara umumnya, pendidikan dari sudut spiritual yang telah dibahaskan oleh Abdullah Nasih Ulwan yang dimuatkan dalam MPIU ini sarat dengan pengajaran dan pembelajaran dalam mendidik anak-anak. Jika diteliti satu persatu unsur di atas, dilihat unsur tersebut mempunyai bentuk pengarahan kendiri atau 
kawalan diri. Ia merupakan salah satu cara bagi seseorang individu khususnya anak-anak untuk mendisiplinkan diri, mengawal serta mengarahkan diri untuk sentiasa berada dalam landasan yang betul. Elemen-elemen tersebut amat sesuai diterapkan ke dalam jiwa anak-anak sejak kecil lagi kerana secara tidak langsung akan mendidik jiwa anak kecil tersebut untuk melalui zaman remaja sehingga menjejaki usia dewasa. Justeru, dengan pendidikan sedemikian, hati anak-anak akan dijinakkan dengan kecintaan kepada Allah, Rasulullah, ibu bapa dan segala bentuk kebaikan. Maka isu remaja lari dari rumah tidak akan timbul apatah lagi apabila kedua ibu bapa menjadi tempat paling istimewa untuk mereka menceritakan hal seharian dan mengadu masalah yang dihadapi mereka.

Selain itu juga, pendidikan keibubapaan yang telah digariskan oleh Abdullah Nasih Ulwan ini banyak mengandungi didikan untuk menghargai diri sendiri yang perlu diterapkan sejak kecil lagi. Jika pendidikan yang diterima oleh anak dengan cara yang betul dari kedua ibu bapanya seperti ibu bapa tidak merendah serta menghina anak mereka dan sebagainya, maka situasi ini akan menimbulkan rasa keyakinan kepada anak-anak dalam memikul tanggungjawab atau telah bersedia untuk menyelesaikan masalah dengan bersikap matang. Hal ini dapat menghindarkan jiwa anakanak yang meningkat remaja untuk mencari jalan penyelesaian dan kepuasan hati di luar rumah dengan mengambil jalan singkat untuk meninggalkan rumah mereka.

Sehubungan dengan itu, model pendidikan keibubapaan ini juga turut menekankan aspek keagamaan dalam memberikan didikan yang sempurna kepada anak-anak sejak dari kecil lagi. Aspek keagamaan ini sangat penting dalam mendidik anak-anak supaya mereka terpandu dengan keterbatasan yang telah digariskan oleh wahyu.

\section{Penutup}

Oleh itu, model ini wajar diketengahkan kepada para ibu bapa bagi membendung gejala-gejala yang tidak diingini nanti khususnya gejala remaja yang lari dari rumah. Usaha murni ini diharapkan memberi manfaat kepada semua pihak yang terlibat untuk merealisasikan usaha membantu remaja dalam menyelesaikan masalah. Peranan keluarga khususnya ibu bapa dalam membentuk 
serta mendidik para remaja yang stabil dari sudut emosi, personaliti dan spiritual adalah amat penting kerana akibat kesilapan didikan ibu bapa akan menyebabkan remaja lebih cenderung untuk melakukan sesuatu tindakan yang negatif antaranya lari dari rumah. Oleh itu peranan atau tanggungjawab ibu bapa bukan sahaja menyediakan keperluan asas, melindungi, membimbing dan menyokong perkembangan fizikal dan psikologi anak-anak, malah ibu bapalah yang bertanggungjawab dalam memastikan remaja dapat mencapai potensi maksimum mereka (Siti Fatimah, 1999: x). Hal ini bertepatan dengan firman Allah S.W.T yang bermaksud:

"Maka dengan sebab rahmat (yang melimpah-limpah) dari Allah (kepadamu wahai Muhammad), engkau telah bersikap lemah-lembut kepada mereka (sahabat-sahabat dan pengikutmu), dan kalaulah engkau bersikap kasar lagi keras hati, tentulah mereka lari dari kelilingmu. Oleh itu maafkanlah mereka (mengenai kesalahan yang mereka lakukan terhadapmu), dan pohonkanlah ampun bagi mereka, dan juga bermesyuaratlah dengan mereka dalam urusan (peperangan dan hal-hal keduniaan) itu. kemudian apabila engkau telah berazam (sesudah bermesyuarat, untuk membuat sesuatu) maka bertawakallah kepada Allah, sesungguhnya Allah Mengasihi orang-orang yang bertawakal kepadaNya" (Surah Âli 'Imrān 3:159)

\section{Rujukan}

"Theories of Adolescence", laman sesawang UK Essays. Dicapai pada, 4 Jan 2013, http://www.ukessays.com/essays/psychology/theories-ofadolescence.php.

Al-Shaban̄̄, 'Umar Muhammad al-Tūmī. Al-Usus al-Nafsiyyah wa al-Tarbawiyyah li Ria'yatī al-Syabāb. Beirut: Dār al'Arabiyyah al-Kitab, 1983.

Abdullah Nasih Ulwan. Pendidikan Anak-anak dalam Islam, terj. Abdullah Semait. Singapura: Pustaka Nasional, 1988.

Akta kanak-kanak 2001; Adam, G. R., \& Gullota, T., Adolescent Life Experiences (California: Wad Sworth Inc., 1983), 421. Al-Ghazālī, Abū Hāamid Muḥammad. Ihyā' 'Ulūm al-Dīn. Beirut: Dār al- Ma'rifah, 1982. 
Al-Ghazālī, Abū Ḥāmid Muḥammad. Mukashafah al-Qulūb. Beirut: Dār al-Jayl, 1991.

Al-Nāsif, Muhammad. F̄̄ Tarbiyah wa Ta 'lìm. Tunis: al-Syarikah al-Tunisiyyah, 1981.

Aristotle. Ethica Nichomachea. New York: Random House, 1941.

Azizi Yahaya et al. Penyelewengan Tingkah Laku Remaja Punca \& Rawatan. Skudai: UTM, 2012.

Azlina Abu Bakar @ Mohd. Psikologi Personaliti Individu. Shah Alam: Karisma Publication Sdn. Bhd., 2005.

Bahagian Perancangan dan Penyelidikan Dasar Pendidikan, Kementerian Pendidikan Malaysia, "Laporan Pengesahan Amalan Peraturan-Peraturan Displin Pelajar Peringkat Sekolah". Kuala Lumpur: Kementerian Pendidikan Malayasia, 1998.

Baumrind, D. "The Influence of Parenting Style on Adolescent Competence And Substance Use", Journal of Early Adolescence, 11, no.1 (1991), 56.

Dra. Netty Hartati, M.Si. et al. Islam dan Psikologi. Jakarta: PT RajaGrafindo Persada, 2004.

Grotevant Harold D. \& R. Cooper Catherine. Individuality and Connectedness in Adolescent Development. London: Routledge, 1998.

Habibah Elias \& Noran Fauziah Yaakub. Psikologi Personaliti. Kuala Lumpur: Dewan Bahasa dan Pustaka, 2006.

Hanif Zakaria \& Mohd Razali Md Nor. "Masalah Remaja Berpeleseran: Satu Kajian Kes di Kuala Lumpur". Kertas Projek, Uitm Shah Alam,1993.

Harlina Halizah Haji Siraj. "Keibubapaan dalam Islam”. Seminar

Keluarga Islam, Kemahiran Keibubapaan dan Cabaran Semasa, 11-12 Mei, 2004.

Helmen, Cecil G. Budaya Kesihatan dan Penyakit, terj. Hasyim Awang. Kuala Lumpur: Dewan Bahasa dan Pustaka, 1994.

Jas Laile Suzana Jaafar. Psikologi Kanak-kanak dan Remaja. Selangor: Arah Publications, 2008.

Johari Alias. Menunaikan Kewajipan dan Tanggungjawab. Kuala Lumpur: Dewan Bahasa dan Pustaka, 1992.

John W Santrock, Life Span Development. New York: McGrawHill, 2007. 
Laman sesawang Utusan Online, dicapai 1 Mei 2013, http://www.utusan.com.my/utusan/Bicara_Agama/20121226/ba _01/Masalah-moral-remaja\#ixzz2S3Yh6or3

Maccoby, E.E. \& Martin, J.A. "Socialization in the Context of Family: Parent-child Interaction", dalam Handbook of Child Psychology, ed. E. M. Hertherington \& P. Mussen. New York: Wiley, 1983.

Mahmood Nazar Muhammad. Pengantar Psikologi: Satu Pengenalan Asas kepada Jiwa dan Tingkah Laku Manusia. Kuala Lumpur: Dewan Bahasa dan Pustaka, 1990.

Mohammad Kamil Abd Majid, "Tanggungjawab Pendidikan Anak-Anak Remaja", Majalah Pengasuh (Januari 1991), 36.

Nelson, Goud \& Abe, Arkoff. Psychology and Personal Growth. USA: Allyn and Bacon, 1998.

Neubeck, Kenneth J \& Neubeck, Marie Alice. Social Problems a Critical Approach. New York: Hill Companies, Inc, 1999.

Nor Azah Abdul Aziz. "Pengawalan Diri ke Atas Pelayaran Laman Web Pornografi pada Peringkat Remaja di Lembah Klang, Malaysia dari Sudut Psikospiritual Islam". Tesis kedoktoran, Universiti Malaya, 2009.

Rousseau, Jean Jacques. Emile or on Education. USA: Basic Books, 1979.

Sabitha Marican, "Penelitian Terhadap Remaja Lari dari Rumah: Punca-punca dan Strategi Penyelesaiannya". Seminar Kebangsaan Gejala Sosial, Jitra, 1995.

Șāliḥ, Muḥammad 'Azmī 'Abd al-Salam. Al-Ta'sil al-Islāmī li Ria'yāt al-Shabāb. Kaherah: Dār al-Șaḥwah, 1985.

Santrock John W. Life Span Development. United Kingdom: McGraw-Hill, 2009. Damsyik: Dār al-Fikr, 1986.

Syed Hassan Syed Ahmad al-Mashoor. "Cabaran Keibubapaan Anak Remaja dan Dewasa". Seminar Keluarga Islam, Kemahiran Keibubapaan dan Cabaran Semasa, 11-12 Mei 2004. White Kathleen M. \& Speisman, Joseph C. Remaja, terj. Maznah Ismail. Kuala Lumpur: Dewan Bahasa dan Pustaka, 1984.

Zinudin. Seluk Beluk Pendidikan Menurut al-Ghazali. Jakarta: Bumi Aksara, 1991. 
Zarrina, Basirah, Sarah dan Faizuri, Model Pendidikan Keibubapaan 